\title{
Aktivitas Antiinflamasi Keladi Belau (Caladium bicolor (W. Ait) Vent.) Terhadap Enzim Siklooksigenase (COX) Secara In Vitro
}

\author{
Nisa Naspiah", ${ }^{1, *}$, Yoppi Iskandar², Moelyono M W², Febrina Mahmudah', Lia \\ Puspitasari $^{1}$ \\ ${ }^{1}$ Fakultas Farmasi, Universitas Mulawarman, Jln. Penajam, Kampus Unmul Gunung \\ Kelua, Kota Samarinda 75119, Provinsi Kalimantan Timur, Indonesia, Telepon dan Fax : \\ 62-0541-739491 \\ Email:nnaspiah@yahoo.com \\ ${ }^{2}$ Fakultas Farmasi, Universitas Padjadjaran, Jln. Raya Bandung - Sumedang Km 21, \\ Jatinangor 45363, Provinsi Jawa Barat, Indonesia
}

\begin{abstract}
Abstrak
Penelitian mengenai aktivitas antiinflamasi keladi belau (Caladium bicolor (W. Ait) Vent.) terhadap enzim siklooksigenase (COX) secara in vitro telah dilakukan. Aktivitas antiinflamasi secara in vitro terhadap enzim COX ditentukan dengan menggunakan metode TMPD (N,N,N',N'-tetrametil-p-fenilendiamin) secara spektrofotometri. Enzim COX yang diuji meliputi enzim COX-1 dan COX-2. Berdasarkan hasil pengujian diketahui ekstrak batang keladi belau mempunyai aktivitas antiinflamasi dengan nilai $\mathrm{IC}_{50}$ sebesar 250,66 ppm terhadap COX-1 dan 255,27 ppm terhadap COX-2. Hasil pengujian menunjukkan bahwa ekstrak tersebut lebih banyak menghambat enzim COX-1.
\end{abstract}

Kata Kunci : Enzim COX-1, Enzim COX-2, Antiinflamasi, Batang Keladi Belau, Metode TMPD.

\begin{abstract}
The research on anti-inflammatory activity of belau caladium (Caladium bicolor (W. Ait) Vent.) against cyclooxygenase (COX) enzyme in vitro has been done. In vitro antiinflammatory activity of COX enzyme used TMPD $\left(N, N, \quad N^{\prime}, \quad N^{\prime}\right.$-tetramethyl-pphenylenediamine) methods by spectrophotometry. COX enzyme tested includes COX-1 and COX-2 enzymes. Based on the test results are known the extract of belau caladium stems has anti-inflammatory activity with IC 50 value of 250,66 ppm against COX-1 and 255,27 ppm against COX-2. The test results showed that extract inhibit COX-1 enzyme more.
\end{abstract}

Keywords : COX-1 Enzyme, COX-2 Enzyme, Anti-inflamation, Belau Caladium Stems, TMPD Methods.

\section{Pendahuluan}

Inflamasi merupakan suatu respon protektif normal terhadap luka jaringan yang disebabkan oleh trauma fisik, zat kimia yang merusak, atau toksin mikroba. Inflamasi disebabkan oleh pelepasan mediator kimia dari jaringan yang rusak dan migrasi sejumlah sel fagositosis (Katzung, 2002).

Mekanisme pengobatan inflamasi oleh obat antiinflamasi dapat dilakukan dengan berbagai cara antara lain dengan menghambat pembentukan mediator radang prostaglandin 
dan menghambat migrasi sel-sel leukosit ke daerah radang (Katzung, 2002). Prostaglandin merupakan mediator inflamasi utama yang paling sering menjadi target pengobatan inflamasi. Mediator ini dihasilkan dari asam arakhidonat melalui jalur siklooksigenase (COX), yang melibatkan enzim COX dalam menghasilkan prostaglandin (Price dan Wilson, 2005).

Enzim COX terdiri atas dua bentuk, yaitu COX-1 dan COX-2 (Turini and Dubois, 2002). Enzim COX-1 berperan untuk memelihara fungsi homeostasis tubuh, sedangkan COX-2 merupakan enzim yang aktivitasnya meningkat selama proses inflamasi. Penghambatan kedua enzim ini oleh obat antiinflamasi dapat menyebabkan terhambatnya pembentukan prostaglandin, sehingga akan mengurangi dan mengatasi kondisi radang atau inflamasi. Namun, selain efek antiinflamasi tersebut, efek lain yang tidak diinginkan juga dapat terjadi, di antaranya gangguan saluran cerna, gangguan pada proses agregasi platelet, dan gangguan pada ginjal (Najirman, 2009). Oleh karena itu, dalam penggunaan obat antiinflamasi perlu diketahui mekanisme penghambatan obat terhadap kedua enzim COX tersebut, sehingga efek yang tidak diinginkan dapat dihindari.

Pengembangan obat antiinflamasi dapat dilakukan dari tumbuhan obat. Golongan senyawa metabolit sekunder yang diketahui mempunyai aktivitas antiinflamasi melalui penghambatan enzim COX adalah golongan terpenoid (Nomura, et al., 2003), fenolat, dan flavonoid (Jachak, et al., 2010).

Tumbuhan Obat di Indonesia yang banyak digunakan sebagai antiinflamasi di salah satu daerah di Kalimantan Timur oleh suatu subetnis, yaitu Subetnis Kutai adalah tumbuhan keladi belau (Caladium bicolor (W. Ait) Vent.). Subetnis Kutai merupakan subetnis di Kalimantan Timur yang masih banyak menggunakan tumbuhan obat untuk pengobatan penyakit. Air rebusan batang keladi belau digunakan oleh masyarakat subetnis tersebut secara tradisional.

Ekstrak batang keladi belau mengandung golongan senyawa metabolit sekunder berupa polifenol dan flavonoid (Ekanem, et al., 2013), sehingga diduga batang tumbuhan ini mempunyai aktivitas antiinflamasi melalui penghambatan enzim COX.

Berdasarkan data ilmiah tersebut dan data empiris dari masyarakat Subetnis Kutai, maka diduga batang keladi belau mempunyai aktivitas sebagai antiinflamasi. Namun, aktivitas antiinflamasinya melalui penghambatan enzim COX secara in vitro belum diketahui secara pasti, sehingga perlu dilakukan penelitian guna mengetahui aktivitas antiinflamasi tumbuhan tersebut menggunakan uji antiinflamasi berupa TMPD (N,N,N',N'-tetrametil-p-fenilendiamin) terhadap enzim COX-1 dan COX-2. Adapun tujuan umum penelitian ini adalah mengetahui aktivitas antiinflamasi ekstrak batang keladi belau melalui uji penghambatan enzim COX menggunakan TMPD.

\section{Bahan dan Metode}

\section{Alat}

Alat-alat yang digunakan dalam penelitian ini, antara lain timbangan analitik Mettler Toledo, panci infus, freeze dryer Telstar, Spektrofotometer UV-Visible Specord 200, mikro pipet Socorex Swiss, vorteks, 96-wells plate Cayman Chemical, microplate reader MRX $\mathrm{TC}$, dan beberapa peralatan gelas yang umum digunakan di laboratorium.

\section{Bahan}

Bahan yang digunakan dalam penelitian ini antara lain batang keladi belau (C. bicolor (W. Ait) Vent.), air suling, kuersetin, DMSO, kit colorimetric COX (ovine) inhibitor screening assay No. 760111 (Cayman Chemical Comp.), pereaksi Folin Ciocalteu, dan larutan $\mathrm{Na}_{2} \mathrm{CO}_{3}$. 


\section{Prosedur Penelitian}

\section{a. Penyiapan Sampel}

Sampel berupa batang keladi belau yang dikumpulkan dari Desa Loleng, Kutai Kartanegara Kalimantan Timur, diolah dengan dicuci menggunakan air bersih, lalu dipotong kecil-kecil dan dikeringkan secara tidak langsung dari sinar matahari, hingga diperoleh simplisia, yang kemudian diinfundasi.

\section{b. Pembuatan Ekstrak}

Sebanyak 167,03 g batang keladi belau dipanaskan dalam $2 \mathrm{~L}$ air selama 15 menit dihitung mulai dari suhu mencapai $90^{\circ} \mathrm{C}$. Setelah itu, dikeringkan menggunakan alat freeze dryer untuk mendapatkan ekstrak kering.

\section{c. Uji Antiinflamasi}

Uji antiinflamasi ini dilakukan menggunakan metode TMPD secara kolorimetri yang tertera pada katalog kit colorimetric COX (ovine) inhibitor screening assay No. 760111. Sebanyak $160 \mu \mathrm{L}$ dapar tris- $\mathrm{HCl}$ dan $10 \mu \mathrm{L}$ heme dimasukkan ke dalam 2 wells sebagai background wells. Dapar tris- $\mathrm{HCl} 150 \mu \mathrm{L}$, heme $10 \mu \mathrm{L}$, dan enzim $10 \mu \mathrm{L}$ dimasukkan dalam 2 wells sebagai $100 \%$ initial activity wells. Dapar tris- $\mathrm{HCl} 150 \mu \mathrm{L}, 10 \mu \mathrm{L}$ heme, enzim $10 \mu \mathrm{L}$, dan $10 \mu \mathrm{L}$ sampel uji dengan konsentrasi $40 \mathrm{ppm}, 80 \mathrm{ppm}, 160 \mathrm{ppm}, 320$ ppm, dan $640 \mathrm{ppm}$ dimasukkan ke dalam inhibitor wells. Pelarut $10 \mu \mathrm{L}$ ditambahkan ke dalam $100 \%$ initial activity wells dan background wells. Plate dikocok beberapa detik dan diinkubasi selama 5 menit pada $25^{\circ} \mathrm{C}$. Larutan substrat kolorimetrik $20 \mu \mathrm{L}$ dan asam arakhidonat $20 \mu \mathrm{L}$ dimasukkan ke dalam semua wells yang digunakan. Plate dikocok secara hati-hati selama beberapa detik dan diinkubasi kembali selama 5 menit pada $25^{\circ} \mathrm{C}$, lalu dilakukan pembacaan absorbansi pada $\lambda 590 \mathrm{~nm}$ menggunakan microplate reader.

Nilai absorbansi background wells, $100 \%$ initial activity wells, dan setiap sampel pada inhibitor wells diambil nilai rata-ratanya, kemudian dilakukan perhitungan sebagai berikut (Cayman Chem. Comp., 2013).

$$
\begin{gathered}
\mathrm{a}=\mathrm{A}_{100 \% \text { initial wells }}-\mathrm{A}_{\text {Background wells }} \\
\mathrm{b}=\mathrm{A}_{\text {Inhibitor wells }}-\mathrm{A}_{\text {Background wells }} \\
\% \text { Penghambatan }=\left(\frac{\mathrm{a}-\mathrm{b}}{\mathrm{a}}\right) \times 100 \%
\end{gathered}
$$

Data persentase penghambatan aktivitas COX-1 dan COX-2 pada masing-masing konsentrasi sampel uji diolah menggunakan analisis regresi linear untuk menentukan $\mathrm{IC}_{50}$ (50\% Inhibition Concentration).

\section{Hasil dan Pembahasan}

Ekstrak batang keladi belau merupakan simplisia batang keladi belau yang telah mengalami proses infundasi dan pengeringan menggunakan alat freeze dryer. Pengujian aktivitas antiinflamasi ekstrak ini dilakukan menggunakan metode TMPD secara kolorimetri. Prinsip metode ini adalah oksidasi satu elektron TMPD oleh aktivitas peroksidase heme menghasilkan senyawa berwarna yang menyerap pada $\lambda 590 \mathrm{~nm}$ (Cayman Chemical Comp., 2013). Semakin banyak aktivitas enzim COX terhadap substrat, maka semakin banyak pula senyawa berwarna dari TMPD yang terbentuk. Hal ini karena pembentukan senyawa berwarna tersebut ekuivalen dengan aktivitas enzim COX dalam mereduksi senyawa PGG2 menjadi PGH2. Metode ini dipilih karena pengerjaannya cepat, reliabel, dan merupakan metode awal untuk melakukan pengujian kemampuan penghambatan enzim COX suatu tumbuhan.

Hasil pengujian aktivitas antiinflamasi dinyatakan dalam nilai $\mathrm{IC}_{50} . \mathrm{IC}_{50}$ merupakan parameter yang menunjukkan konsentrasi zat yang diperlukan untuk menghambat $50 \%$ 
aktivitas COX (Najirman, 2009). Hasil pengujian aktivitas antiinflamasi ekstrak batang keladi belau terhadap enzim COX dapat dilihat pada Tabel 1.

Tabel 1. Hasil Pengujian Aktivitas Antiinflamasi Ekstrak Batang Keladi Belau Terhadap Enzim COX

\begin{tabular}{ccccc}
\hline \multirow{2}{*}{$\begin{array}{c}\text { Konsentrasi } \\
(\mathrm{ppm})\end{array}$} & $\begin{array}{c}\text { Persen } \\
\text { Penghambatan }(\%)\end{array}$ & $\mathrm{IC}_{50}(\mathrm{ppm})$ & $\begin{array}{c}\text { Persen } \\
\text { Penghambatan }(\%)\end{array}$ & $\mathrm{IC}_{50}(\mathrm{ppm})$ \\
\hline 40 & 29,27 & & 33,33 & \\
80 & 31,71 & & 36,84 & \\
160 & 48,78 & 250,66 & 47,37 & 255,27 \\
320 & 61,79 & & 61,40 & \\
640 & 77,24 & & 68,42 & \\
\hline
\end{tabular}

Berdasarkan hasil pengujian, ekstrak batang keladi belau mempunyai aktivitas antiinflamasi melalui penghambatan enzim COX. Ekstrak ini lebih banyak menghambat enzim COX-1 dibandingkan COX-2. Hal ini karena nilai $\mathrm{IC}_{50}$ pada pengujian ke COX-1, yaitu 250,66 ppm lebih kecil dibandingkan pada pengujian ke COX-2, yaitu 255,27ppm.

\section{Ucapan Terima Kasih}

Peneliti mengucapkan terima kasih kepada DIKTI yang telah membantu membiayai penelitian melalui Program Beasiswa Unggulan tahun 2012.

\section{Daftar Pustaka}

Alfian, Riza dan Susanti, Hari. 2012. Penetapan Kadar Fenolik Total Ekstrak Metanol Kelopak Bunga Rosella Merah (Hibiscus sabdariffa Linn) Dengan Variasi Tempat Tumbuh Secara Spektrofotometri. Jurnal Ilmiah Kefarmasian, 9 (1) : 73-80.

Cayman Chemical Company. 2013. Colorimetric COX (Ovine) Inhibitor Screening Assay Kit : Item No. 760111. USA : Cayman Chemical Company.

Ekanem, B. E., A.N., Osuagwu, Aikpopodion, P., I.A., Ekpo, R.B., Agbor, and Y.B., Ibiang. 2013. Hytochemical Composition of Caladium Species. Global J Med Plant Res, 1 (1) : 132-135.

Jachak, Sanjay M., Gautam, Raju, Selvam, C., Madhan, Himanshu, Srivastava, and Khan, Taj. 2010. Anti-inflammatory, cyclooxygenase inhibitory and antioxidant activities of standardized extracts of Tridax procumbens L. Fitoterapia (2010).

Najirman. 2009. Buku Ajar Ilmu Penyakit Dalam. Jakarta : Internapublishing.

Nomura, Masato, Kasemura, Kazuo, Fujihara, Yoshihiton, and Inoue, Toshio. 2003. Proinflammatory Cytokine (TNF- $\alpha$ ) Suppression of Various Terpenoids to Human Monocytic Cell. Research Reports of The School of Engineering, Kinki University, $37: 1-5$

Price, S.A. dan Wilson, L.M.. 2005. Patofisiologi : Konsep Klinis Proses-Proses Penyakit, Edisi 6/Vol. 2. Terjemahan Brahm U. Pendit, Huriawati Hartanto, Pita Wulansari, Dewi Asih Mahanani. Jakarta : Penerbit EGC.

Turini, Marco E. And Dubois, Raymond N.. 2002. Cyclooxygenase-2 : Therapeutic Target. Annu Rev Med, 53 : 35-37. 